\title{
PELATIHAN PENELITIAN TINDAKAN KELAS (PTK) BAGI GURU SMKN 1 KECAMATAN MEMPURA KABUPATEN SIAK
}

\author{
Lega Putri Utami*, Legisnal Hakim, Ahmad Kafrawi Nasution, Sunaryo, \\ Abrar Ridwan, Budi Istana, Afdal, Ridwan Abdurahaman \\ Program Studi Teknik Mesin, Fakultas Teknik \\ Universitas Muhammadiyah Riau \\ email: legaputri@umri.ac.id
}

\begin{abstract}
Classroom Action Research (CAR) is research conducted by teachers in their own class by planning, implementing and reflecting actions collaboratively and participatively with the aim of improving performance as a teacher so that student learning outcomes can improve. Thus PTK can facilitate teachers to develop an understanding of pedagogy in order to improve their learning.

This training also invites teacher friends to step into various records that after being processed can manifest into a quality study. Carry out research on what is done daily by a teacher who can finally produce a work called PTK. This can happen if a general sequence of procedures, which starts from the identification of research problems encountered until the final report is recorded. So, it is very important that this procedure is understood and adhered to by the teacher who is researching.

The overall service activities are quite good in terms of the target number of participants and enthusiasm in receiving the material provided.
\end{abstract}

Keywords: Training, Writing, PTK, Vocational Teacher

\begin{abstract}
Abstrak
Penelitian Tindakan Kelas (PTK) adalah penelitian yang dilakukan guru di kelasnya sendiri dengan cara merencanakan, melaksanakan dan merefleksikan tindakan secara kolaboratif dan partisipatif dengan tujuan memperbaiki kinerja sebagai guru sehingga hasil belajar siswa dapat meningkat. Dengan demikian PTK dapat memfasilitasi guru untuk mengembangka pemahaman pedagogi dalam rangka memperbaiki pembelajarannya.

Pelatihan ini juga mengajak teman-teman guru untuk melangkah kepada berbagai catatan yang setelah diolah dapat mewujud menjadi suatu penelitian yang berkualitas. Melaksanakan penelitian tentang apa yang sehari-hari dilakukan oleh seorang guru yang akhirnya dapat menghasilkan suatu karya yang disebut PTK. Hal itu dapat terjadi apabila suatu urutan umum prosedur, yaitu bermula dari identifikasi masalah penelitian yang dihadapi sampai dengan laporan hasil akhirnya dicatat. Jadi, amat penting suatu prosedur ini dipahami dan ditaati oleh guru yang meneliti.

Kegiatan pengabdian secara keseluruhan cukup baik dilihat dari target jumlah peserta serta antusiasme dalam menerima materi yang diberikan.
\end{abstract}

Kata Kunci: Pelatihan, Penulisan, PTK, Guru SMK 


\section{PENDAHULUAN}

Berdasarkan Peraturan Pemerintah No. 74 Tahun 2008 Tentang Guru, penulisan karya tulis ilmiah kini menjadi persyaratan penting untuk guru dalam kenaikan golongannya dalam bidang pengembangan profesi. Ada beberapa macam karya tulis ilmiah, salah satunya yang cukup diminati adalah karya tulis ilmiah hasil penelitian. Dalam hal ini yang cukup diminati para guru adalah karya tulis ilmiah dengan menggunakan pengalaman guru sendiri yaitu dengan penelitian tindakan kelas (PTK). PTK adalah penelitian yang dilakukan guru di kelasnya sendiri dengan cara merencanakan, melaksanakan dan merefleksikan tindakan secara kolaboratif dan partisipatif dengan tujuan memperbaiki kinerja sebagai guru sehingga hasil belajar siswa dapat meningkat (WijayaKusuma 2010). Dengan demikian PTK dapat memfasilitasi guru untuk mengembangkan pemahaman pedagogi dalam rangka memperbaiki pembelajarannya.

Pelatihan ini juga mengajak temanteman guru untuk melangkah kepada berbagai catatan yang setelah diolah dapat mewujud menjadi suatu penelitian yang berkualitas. Melaksanakan penelitian tentang apa yang sehari-hari dilakukan oleh seorang guru yang akhirnya dapat menghasilkan suatu karya yang disebut PTK. Hal itu dapat terjadi apabila suatu urutan umum prosedur, yaitu bermula dari identifikasi masalah penelitian yang dihadapi sampai dengan laporan hasil akhirnya dicatat. Jadi, amat penting suatu prosedur ini dipahami dan ditaati oleh guru yang meneliti.

\section{METODE PENGGABDIAN}

Untuk mencapai tujuan dan target yang akan dicapai maka perlu dibentuk metode atau program sebagai solusinya, adapun metodenya adalah melakukan pelatihan dan PTK di kecamatan Mempura, Kabupaten Siak. Peserta pelatihan yaitu Guru SMKN 1 Menpura.
Pelatihan dilakukan selama 1 hari dengan maksimal peserta 25 orang. Materi yang akan diberikan sebagai berikut:

1.) Mengenal PTK

Dalam sesi materi ini peserta akan termotivasi untuk menulis sekaligus mengenal apa dan bagaimana penelitian tindakan kelas beserta landasan pemikiran PTK.

2.) Memulai dengan PTK

3.) Dalam pelatihan ini peserta akan mendapat pengenalan dasar PTK dan pengenalan tahap melaksanakan PTK dan mulai menulis bab pendahuluan.

4.) Menulis PTK

Selain pengenalan dasar dan tahap pelaksanaan PTK, peserta akan mendapat pengenalan sistematika PTK dan mulai menulis bab pendahuluan.

5.) Manajemen Referensi

\section{HASIL DAN PEMBAHASAN}

Kegiatan pengabdian dosen dengan judul Pelatihan penulisan Penelitian Tindakan Kelas dilaksanakan di labor Bahasa SMK N 1 Kecamatan Mempura Kabupaten Siak selama satu hari. Pertemuan ini dihadiri oleh 11 orang guru

Agenda kegiatan pengabdian di labor bahasa dilakukan dengan pemaparan materi yang disampaikan oleh tim dosen. Penyampaian materi dari Tim antara lain Materi PTK (prinsip, prosedur dan implemantasi), Cara penulisan dengan standar ilmiah dan manajemen referensi. Penyampaian materi dilanjutkan dengan sesi Tanya jawab dan diskusi mengenai berbagai kendala yang dihadapi guru dalam PTK dan penulisan laporannya.

Kegiatan pengabdian dilanjutkan dengan pendampingan yaitu guru yang sedang membuat PTK dipersilahkan berkonsultasi dengan tim melalui wa grup yang telah dibuat untuk mendapatkan masukan dalam rangka perbaikan. Pendampingan dilakukan oleh tim pengabdi dengan harapan semakin banyak guru SMK mengimplementasikan PTK dan menulis laporannya. 
Hasil pelaksanaan kegiatan pengabdian secara keseluruhan dapat dilihat berdasarkan komponen di bawah ini

a. Ketercapaian target jumlah peserta Pelatihan

Target peserta pelatihan yang direncanakan adalah sebanyak 25 orang guru yang terdiri dari perwakilan Guru bidang Produksi. Dalam pelaksanaannya kegiatan ini hanya di ikuti oleh 11 orang guru. Hal ini disebabkan oleh waktu yang dilakasanakan pada hari jumat, dimana guru banyak berasal dari kota Pekanbaru dan mereka kembali ke Pekanbaru. Guru yang berada di sekolah tinggal guru yang berasal dari siak saja.

b. Ketercapaian Tujuan Pelatihan Ketercapaian tujuan dalam pelatihan dapat dikatakan belum baik karena belum banyak guru yang memberikan laporan PTK nya dan keterbatasan pendamping. Hal ini disebabkan banyaknya kesibukan disekolah maupun kesibukan tim dosen.

c. Ketercapaian Target Materi Yang Telah Direncanakan.

Ketercapaian target materi yang telah direncanakan cukup baik walaupun ada beberapa materi yang belum tersampaikan, karena waktu yang tidak mencukupi.

d. Kemampuan Peserta dalam Penguasaan MateriSecara umum.

e. peserta sangat antusias dalam menerima materi, karena mereka mengaku sangat membutuhkan materi pelatihan PTK. Selama ini jarang mendapatkan pelatihan tentang PTK dan cara menulis dari Pemerintah.

Secara Keseluruhan, kegiatan pengabdian di SMK N 1 Mempura terlaksana dengan cukup baik berkat dukungan Kepala sekolah dan wakil Kepala Sekolah beserta guru.

\section{SIMPULAN}

Kegiatan pengabdian yang dilakukan oleh Tim Program Studi Teknik Mesin UMRI dengan metode ceramah dan diskusi telah mampu meningkatkan pemahaman guru SMK N 1 Mempura tentang PTK dan di harapkan dapat sekaligus menulis laporannya. Penulisan laporan PTK diharapkan sebagai pengembangan profesi dan dapat membantu guru dalam pencapaian angka kredit untuk kenaikan pangkat.

\section{UCAPAN TERIMAKASIH}

Kami mengucapkan terima kasih yang sebesar-besarnya kepada:

1. Univeristas Muhammadiyah Riau, sebagai lembaga yang menyediakan sarana tempat untuk pelatihan ini.

2. Lembaga Penelitian dan Pengabdian Kepada Masyarakat UMRI yang telah memberikan kemudahan berupa bantuan dana dan fasilitas pelaksanaan pengabdian.

3. Kepala Sekolah SMK N 1 Mempura yang telah memberikan waktu dan fasilitas serta bantuan selama melakukan pengabdian

4. Seluruh peserta pelatihan yang telah meluangkan waktunya sehingga terselenggaranya kegiatan ini.

\section{DAFTAR PUSTAKA}

[1] Mulyasa, H.E. (2009). "Praktik Penelitian Tindakan Kelas, Bandung: PT Remaja RosdaKarya

[2] Undang - Undang Republik Indonesia No 14 Tahun 2005 Tentang Guru dan Dosen

[3] Suharsimi Arikunto, Suhardjono dan Supardi. (2008). "Penelitian Tindakan Kelas" Jakarta: Bumi Aksara

[4] Wina Sanjaya (2010). "Penelitian Tindakan Kelas" Jakarta: Kencana 